\title{
The Effect of Temozolomide on the Prevention of Epidural Fibrosis Developing after Lumbar Laminectomy in Rats
}

\author{
Ratlarda Lomber Laminektomi Sonrası Ortaya Çıkan Epidural \\ Fibrozisin Önlenmesinde Temozolamidin Etkisi
}

Ozgen AYDINCAK ${ }^{1}$, Muhammet Bahadır YILMAZ ${ }^{1}$, Hakan EMMEZ ${ }^{1}$, Gokhan KURT ${ }^{1}$, Aylin SEPICI ${ }^{2}$, Leyla MEMIS ${ }^{3}$, Kemali BAYKANER ${ }^{1}$

${ }^{1}$ Gazi University, Faculty of Medicine, Departments of Neurosurgery, Ankara, Turkey

${ }^{2}$ Gazi University, Faculty of Medicine, Departments of Medical Biochemistry, Ankara, Turkey

${ }_{3}$ Gazi University, Faculty of Medicine, Departments of Pathology, Ankara, Turkey

Presented in: This paper was presented at the XXIInd Congress of Turkish Neurosurgical Society Antalya, 2008.

Correspondence address: Muhammet BahadırYILMAZ / E-mail: mbahadiryilmaz@yahoo.com.tr

\begin{abstract}
AIM: Failed back surgery syndrome is observed in $15 \%$ of patients who have undergone surgery for lumbar disk hernia.Excess epidural fibrosis is the etiology in $24 \%$ of FBSS cases. This study was conducted with the belief that the antiproliferative effect of temozolomide can prevent epidural fibrosis.

MATERIAL and METHODS: 8 rats (Group I) underwent laminectomy and were then administered saline while 6 rats (Group II) were administered temozolomide at a dose of $18 \mathrm{mg} / \mathrm{kg} /$ day for 5 days after the surgery to make up a total of 14 male Wistar rats used. The pathology preparations of subjects sacrificed at the end of week 6 were histopathologically examined with the Hematoxylin-Eosin stain and Trichrome stain. The pathology preparations were assessed with the analysis parameters and scale generated by He et al. The results were analyzed with the Chisquare test.

RESULTS: No significant difference was found between the two groups in terms of bone and cartilage regeneration, arachnoidal fibrosis, and inflammatory and fibroblast cell densities. Epidural fibrosis formation was significantly less and there was no grade III fibrosis in the Temozolomide group. This was found to be statistically significant $(p=0.0302)$. No side effect of dural or intradural damage was observed.

CONCLUSION: Temozolomide was found to be effective in preventing epidural fibrosis. However, further research is required to determine its effectiveness in local applications and the appropriate dose range.
\end{abstract}

KEYWORDS: Temozolomide, Epidural fibrosis, Anti-proliferative drug, Laminectomy, Failed back surgery syndrome

Öz

AMAÇ: Lomber disk hernisi için cerrahi uygulananların \%15'inde başarısız bel cerrahisi sendromu görülmektedir. BBCS etyolojisinin de \%24'ünü aşırı epidural fibrozis oluşturmaktadır. Bu çalışma temazolomidin antiproliferatif etkisiyle epidural fibrozisi önleyebileceği düşünülerek yapılmıştır.

YÖNTEM ve GEREÇLER: Laminektomi uygulanıp serum fizyolojik verilen 8 rat (Grup I) ve operasyon sonrası 5 gün boyunca 18mg/kg/gün dozda olacak şekilde temozolomid verilen 6 rat (Grup II) olmak üzere toplam 14 Wistar cinsi erkek rat kullanıldı. 6 . hafta sonunda sakrifiye edilen deneklerin patolojik preparatları, Hematoksilen Eozin ve Trikrom boyalarıyla histopatolojik incelemeye alındı. Patolojik preparatlar He ve arkadaşlarının oluşturduğu analiz parametreleri ve skala ile değerlendirildi. Çıkan sonuçlar Ki-kare testiyle değerlendirildi.

BULGULAR: Her iki grup arasında kemik ve kıkırdak rejenerasyonu, araknoidal fibrozis, inflamatuvar ve fibroblast hücre yoğunluğu açısından anlamlı fark saptanmadı. Epidural fibrozis oluşumu ise Temozolomid grubunda belirgin daha azdı ve grade III fibrozise hiç rastlanmadı. Bu istatistiki olarak da anlamlı bulundu $(p=0,0302)$. Yan etki olarak dura ve intradural yapılarda hasarlanma tespit edilmedi.

SONUÇ: Temozolomidin epidural fibrozisi önlemede etkili olduğu saptanmıştır. Ancak özellikle lokal uygulamada etkinliğinin ve uygun doz aralığının saptanması için ileri araştırmalar gerekmektedir.

ANAHTAR SÖZCÜKLER: Temozolomid, Epidural fibrozis, Antiproliferatif ilaç, Laminektomi, Başarısız bel cerrahisi sendromu 


\section{INTRODUCTION}

Lumbar disk hernia is one of the most common causes of lower back pain and is observed in the general population at a rate of $2-40 \%$ with only $15 \%$ requiring surgical treatment $(11,17,25)$. Failed back surgery syndrome (FBSS) is observed in $15 \%$ of those that undergo surgical treatment $(1,20)$. There are many factors in the etiology of FBSS but approximately $24 \%$ of these cases are caused by epidural fibrosis (3). Epidural fibrosis is commonly observed after spinal decompressive surgery but the full clinical picture occurs in only $1-2 \%$ of patients (21). The developing fibrosis causes radicular pain by pulling, stretching and generating pressure on the nerve roots. Although there is no problem in the early postoperative period, pain and sensory and motor deficits may appear after 3 to 6 months $(2,3,23)$. The success rate in patients reoperated due to epidural fibrosis ranges between $30-37 \%$ and $10-20 \%$ of cases have been reported to worsen $(4,22)$. The risk of dural injury and arachnoiditis is also very high in these cases. Epidural fibrosis encountered after lumbar disk hernia or lumbar spinal stenosis surgery constitutes one of the problems that need to be overcome due to its incidence, difficulties in treatment, workforce losses, and the diagnosis and treatment costs.

Many drugs including antineoplastics have been tried to prevent this undesirable condition. Temozolomide is an imidazotetrazinone derivative and it exerts its antiproliferative effect by stopping the G2/M stage transition in proliferating cells. This study was conducted to evaluate whether the anti-proliferative effect of temozolomide could prevent epidural fibrosis.

\section{MATERIALS and METHODS}

This study was carried out at the Gazi University Experimental Animals Research Center after obtaining approval from the medical faculty ethics committee (GUERC). A total of 14 male Wistar rats with weights of $200+/-20$ gr were used in this study. The subjects were divided into two groups. Group I $(\mathrm{N}=8)$ was the control group that underwent L3 and L4 laminectomy while Group II ( $\mathrm{N}=6)$ was the group that underwent $\mathrm{L} 3$ and $\mathrm{L} 4$ laminectomy and then was administered temozolomide at a dose of $18 \mathrm{mg} / \mathrm{kg} /$ day for 5 days after the surgery (27).

\section{Operating procedure}

All surgical interventions were performed under sterile conditions. General anesthesia was achieved with $5 \mathrm{mg} / \mathrm{kg}$ xylazine (Rompun, Bayer, Istanbul/Turkey) and 60-100 mg/ $\mathrm{kg}$ ketamine hydrochloride (Ketalar, Eczacibası, Istanbul/ Turkey). The depth of anesthesia was assessed by giving a painful stimulus from the tail every 15 minutes. Following immobilization of the subjects to the operation table, they were first numbered at the inner surface of their ears. The lumbar region was then shaved. The operation area was sterilized with $10 \%$ polyvinylpyrrolidone-iodine mixture. The lumbar fascia was opened after making a midline skin incision approximately $3 \mathrm{~cm}$ long over the spinous processes. The paravertebral muscles were subperiosteally dissected from the spinous processes and laminas. The operation site was exposed via small automated retractors. L3 and L4 total laminectomy was performed with a small rongeur and highspeed drill (Aesculap Microtron GD 412, Tuttlingen, Germany) using the surgical microscope (Opmi 99, Carl Zeiss, Germany). The ligamentum flavum and epidural fat tissue were excised. Durameter and nerve roots were exposed (Figure 1). After washing the site with saline, the fascia was sutured with $5 / 0$ vicryl. The skin was sutured with $4 / 0$ silk. The operation site was cleaned again with $10 \%$ polyvinylpyyrolidone-iodine mixture. The animals were kept in a room at $28^{\circ} \mathrm{C}$ for about 30 minutes while they recovered from anesthesia. Loss of strength in the lower extremities was not detected in the postoperative early neurological examinations of the animals. The subjects in Group II underwent the same procedure but were also administered temozolomide at a dose of $18 \mathrm{mg} / \mathrm{kg} /$ day for 5 days after the surgery (27).

The rats were sacrificed with the intraperitoneal injection of a lethal dose of sodium pentothal at the end of 6 weeks. The vertebral column was transversely cut approximately $0.5 \mathrm{~cm}$ above and below the laminectomy site with a number 20 scalpel while preserving the lumbosacral fascia. The vertebral column was then removed as a block and placed into $10 \%$ formalin solution.

\section{Histological study}

The lumbar spinal blocks were kept in 10\% buffered formalin for 1 week for histopathological analysis. They were then decalcified with $90 \%$ formic acid. The vertebral column was macroscopically sectioned at $5 \mathrm{~mm}$ intervals. Each section was preserved with spinal roots within the dura along the vertebral canal. Sections were paraffin-embedded after tissue processing. $6 \mu \mathrm{m}$-thick sections were taken from each slice

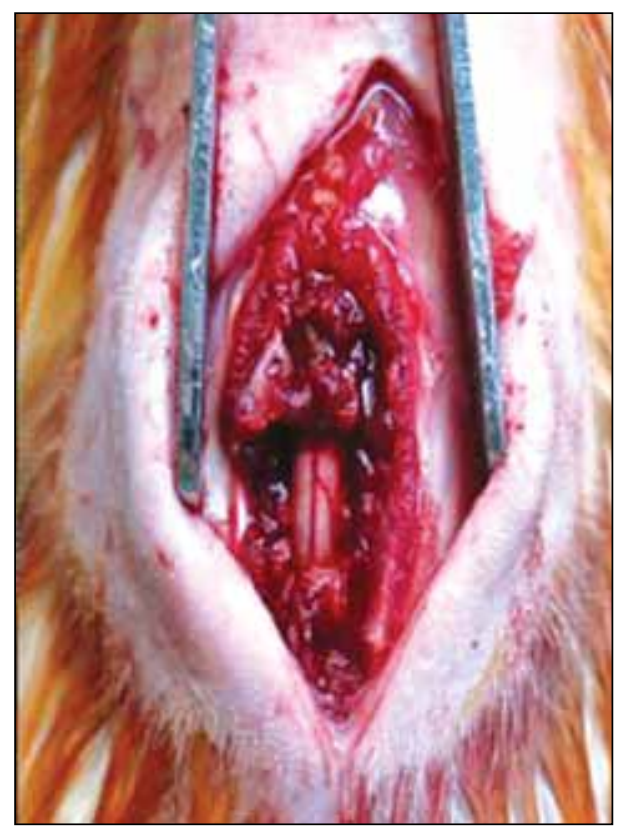

Figure 1: The dura is seen after $L 3$ and $L 4$ total laminectomy, and ligamentum flavum and epidural fat excision. 
with the microtome and were subjected to HematoxylinEosin (HE) and Trichrome staining. Epidural fibrosis, fibroblast and inflammatory cell densities, arachnoidal adhesions, bone regeneration, and cartilage regeneration in the area from the lumbosacral fascia to the dura mater and nerve root were evaluated at the Gazi University Faculty of Medicine, Department of Pathology using the analysis parameters and scale generated by He et al. (13).

\section{Statistical methods}

The results were compared using the Chi-square test to evaluate whether they were statistically significant.

\section{Result}

He and Revel's criteria were used for the assessment conducted together with the Department of Pathology. ${ }^{13}$ None of the subjects had a neurological deficit, CSF leakage or infection. No difference was detected for the healing of skin and lumbosacral fascia. No statistically significant difference was found between the groups in terms of bone and cartilage regeneration, arachnoidal fibrosis, and inflammatory and fibroblast cell densities $(p=0.94, p=0.59, p=0.78, p=0.797$, $\mathrm{p}=0.485$ respectively) (Table $\mathrm{I}, \mathrm{II}, \mathrm{III})$. In terms of epidural fibrosis, there was a significant difference in the group administered Temozolomide $(p=0.0302)$ where no grade 3 fibrosis not observed. Damage to the dura and intradural structures was not found as a side effect of the medication.

In the control group, grade III fibrosis was found in 4 subjects (50\%) and grade II fibrosis also in 4 subjects (50\%) (Figure 2). Fibroblast densities were consistent with grade II in 4 subjects (50\%) (Figure 3) and with grade I was in the remaining 4 subjects (50\%). Five subjects (62.5\%) were observed to have significant inflammatory cells (Figure 4) while a level of grade I was observed in 3 subjects (37.5\%). Bone regeneration was found in 4 subjects (50\%) and cartilage regeneration in 3 subjects (37.5\%) Arachnoidal fibrosis was observed in only two subjects (25\%) (Table I, II, III).

In the Temozolomide group, grade II fibrosis was determined in 3 subjects (50\%) and grade I fibrosis in 3 subjects while

Table I: Histopathological Findings of the Control and Drug Groups. Subjects in Group I are Shown with C and in Subjects in Group II with T

\begin{tabular}{|c|c|c|c|c|c|c|c|}
\hline & $\begin{array}{l}\text { Fibrosis in } \\
\text { Dura mater } \\
\text { (Grade) }\end{array}$ & $\begin{array}{l}\text { Fibroblast } \\
\text { Density } \\
\text { (Grade) }\end{array}$ & $\begin{array}{l}\text { Inflammatory } \\
\text { Cell Density } \\
\text { (Grade) }\end{array}$ & $\begin{array}{c}\text { Bone } \\
\text { Regeneration }\end{array}$ & $\begin{array}{c}\text { Cartilage } \\
\text { Regeneration }\end{array}$ & $\begin{array}{l}\text { Arachnoidal } \\
\text { Fibrosis }\end{array}$ & $\begin{array}{c}\text { Macroscopic } \\
\text { Fibrosis }\end{array}$ \\
\hline C1 & 3 & 2 & 1 & + & - & + & 3 \\
\hline $\mathrm{C} 2$ & 3 & 2 & 1 & + & + & - & 3 \\
\hline C3 & 2 & 2 & 2 & - & - & - & 2 \\
\hline C4 & 2 & 1 & 2 & - & - & - & 2 \\
\hline $\mathrm{C} 5$ & 2 & 1 & 2 & - & - & - & 1 \\
\hline C6 & 3 & 2 & 2 & + & + & + & 3 \\
\hline$C 7$ & 3 & 1 & 1 & + & + & - & 2 \\
\hline C8 & 2 & 1 & 2 & - & - & - & 3 \\
\hline $\mathrm{T} 1$ & 1 & 1 & 1 & - & - & - & 1 \\
\hline T2 & 1 & 3 & 1 & - & - & - & 2 \\
\hline T3 & 2 & 2 & 1 & - & - & + & 2 \\
\hline T4 & 1 & 1 & 1 & - & - & - & 1 \\
\hline T5 & 2 & 1 & 2 & + & + & - & 2 \\
\hline T6 & 2 & 2 & 1 & + & + & - & 2 \\
\hline
\end{tabular}

Table II: Epidural Fibrosis, Inflammatory Cell and Fibroblast Densities in the Control and Drug Groups

\begin{tabular}{|c|c|c|c|c|c|}
\hline & & Grade I & Grade II & Grade III & $\mathbf{p}$ \\
\hline Epidural fibrosis & $\begin{array}{l}\text { Control } \\
\text { Temozolomide }\end{array}$ & $\begin{array}{l}0.00 \\
3(50 \%)\end{array}$ & $\begin{array}{l}4(50 \%) \\
3(50 \%)\end{array}$ & $\begin{array}{l}4(50 \%) \\
0.00\end{array}$ & $\underline{0.03}$ \\
\hline $\begin{array}{l}\text { Inflammatory cell } \\
\text { density }\end{array}$ & $\begin{array}{l}\text { Control } \\
\text { Temozolomide }\end{array}$ & $\begin{array}{ll}5 & (62.5 \%) \\
5 & (83.5 \%)\end{array}$ & $\begin{array}{l}3(37.5 \%) \\
1(16.5 \%)\end{array}$ & $\begin{array}{l}0.00 \\
0.00\end{array}$ & $p=0.797$ \\
\hline Fibroblast density & $\begin{array}{l}\text { Control } \\
\text { Temozolomide }\end{array}$ & $\begin{array}{l}4(50 \%) \\
3(50 \%)\end{array}$ & $\begin{array}{l}4(50 \%) \\
2(33.5 \%)\end{array}$ & $\begin{array}{l}0.00 \\
1(16.5 \%)\end{array}$ & $p=0.485$ \\
\hline
\end{tabular}


Table III: Arachnoidal Fibrosis, Bone and Cartilage Regeneration in the Control and Drug Groups

\begin{tabular}{|c|c|c|c|c|}
\hline & & $(-)$ & $(+)$ & $\mathbf{p}$ \\
\hline Arachnoidal fibrosis & $\begin{array}{l}\text { Control } \\
\text { Temozolomide }\end{array}$ & $\begin{array}{l}6(75 \%) \\
5(83.5 \%)\end{array}$ & $\begin{array}{l}2(25 \%) \\
1(16.5 \%)\end{array}$ & 0.78 \\
\hline Bone regeneration & $\begin{array}{l}\text { Control } \\
\text { Temozolomide }\end{array}$ & $\begin{array}{l}4(50 \%) \\
4(67 \%)\end{array}$ & $\begin{array}{l}4(50 \%) \\
2(33 \%)\end{array}$ & 0.94 \\
\hline Cartilage regeneration & $\begin{array}{l}\text { Control } \\
\text { Temozolomide }\end{array}$ & $\begin{array}{l}5(62.5 \%) \\
4(67 \%)\end{array}$ & $\begin{array}{l}3(37.5 \%) \\
2(33 \%)\end{array}$ & 0.59 \\
\hline
\end{tabular}

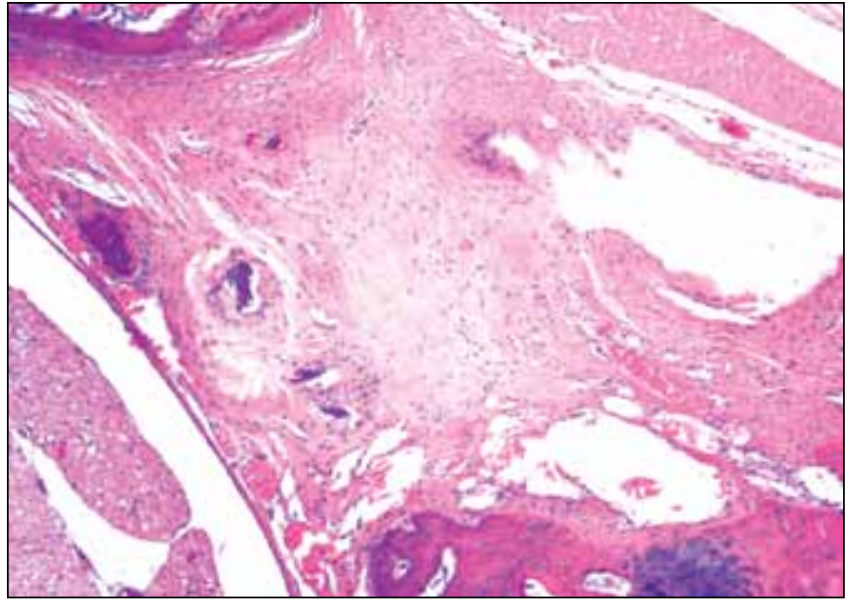

Figure 2: The appearance of grade III fibroblast cell density (Hematoxylin-Eosin stain, 200x).

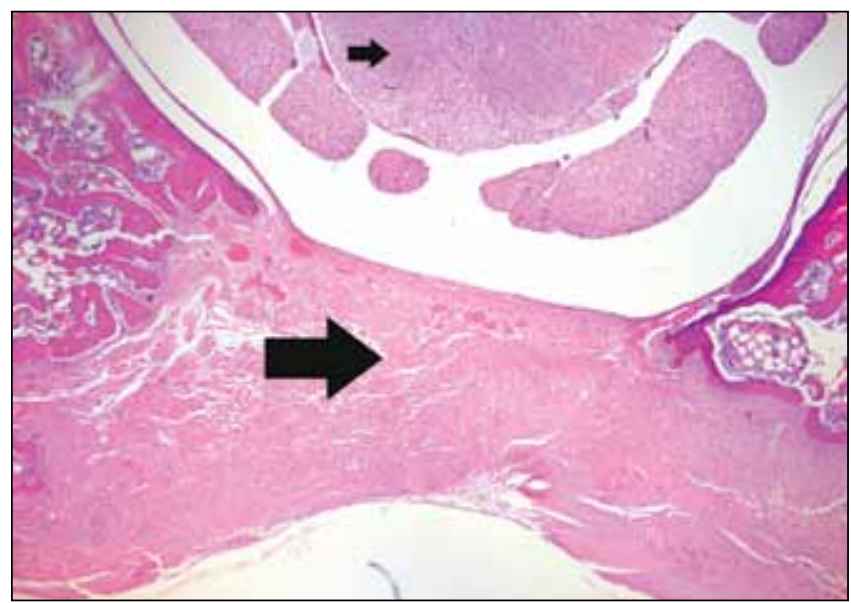

Figure 4: The appearance of grade II inflammatory cell density (Large arrow: area with intense inflammatory cells, Small arrow: medulla spinalis) (Hematoxylin-Eosin stain, 100x).

none of the cases had grade III fibrosis $(p=0.0302)$. Fibroblast density was grade III in 1 subject (16.5\%), grade II in 2 subjects (33\%) and grade III in 3 subjects (50\%). Grade I inflammatory cell density was observed in 5 patients (83\%) while grade II was found in only 1 subject (16.5\%). Bone regeneration was found in 2 subjects (33\%), cartilage regeneration in 2 subjects (33\%) and arachnoidal fibrosis in only 1 subject (16.5\%).

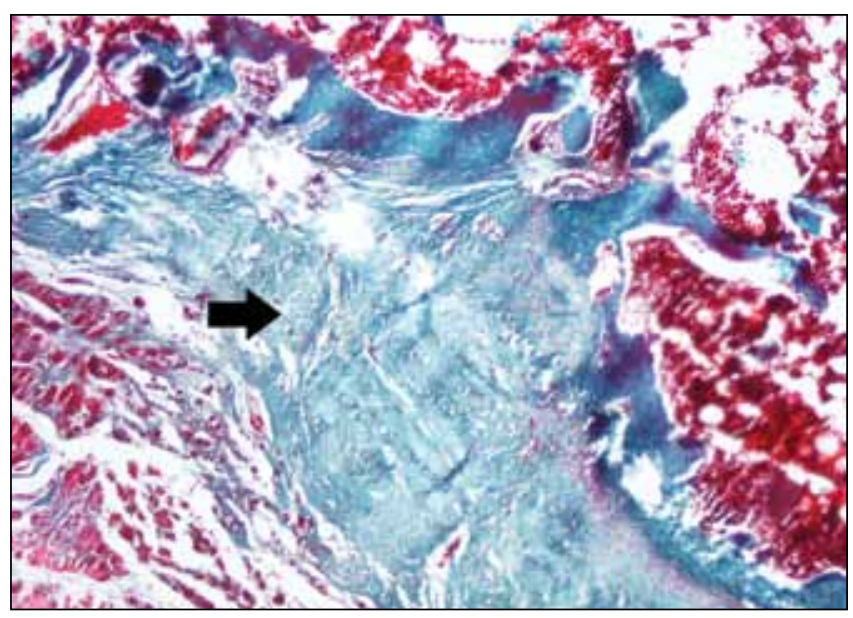

Figure 3: The appearance of grade II microscopic fibrosis (black arrow: epidural fibrosis) (Trichrome stain, 100x).

\section{DISCUSSION}

The failed back surgery syndrome is a burden to the economy because of the wide spectrum of treatment methods and the associated large cost. Microsurgery and neuroendoscopic techniques continue to be the most important methods in reducing epidural fibrosis resulting after laminectomy as they cause less tissue damage and reduce the volume of deadspace. Discontented patient profile, treatment difficulties, loss of workforce, and the diagnosis and treatment costs when epidural fibrosis occurs in spinal surgery has led to many studies being conducted on this problem An attempt has been made to decrease fibrosis with existing materials although it has not been possible to completely eliminate it. Successful results have not been achieved at the desired level. Many agents such as nonsteroidal anti-inflammatory drugs (13), gel foam (22), fat grafts, gore-tex (5), carboxymethylcellulose (15), polyactive membrane (6) and ADCON-L (16) have been used in the literature. There are also studies on chemotherapeutic agents that are capable of inhibiting cell division and increasing apoptosis in the treatment of epidural fibrosis. 5-Fluorouracil (24), mitomycin C $(8,18,19,26)$, cyclosporine A (26) are some of the chemotherapeutic agents used in the prevention of epidural fibrosis and reported to have successful results.

Autogenic fat grafts are one of the most commonly used clinical and experimental materials and have been shown 
to reduce adhesions by providing a good anatomical plane between the dura mater and surrounding tissue (12). However, it should be noted that $50 \%$ of the volume is gradually lost and they may cause symptomatic pressure on nerve roots.

Corticosteroids have been administered topically and systematically by clinicians in order to prevent epidural fibrosis, to reduce the inflammatory cell response and also to increase the activity of collagenases (10). However, there is insufficient evidence in the literature about steroids regarding prevention of epidural fibrosis as far as we know. He and Revel reported $40 \%$ less epidural fibrosis in the treatment group with ketoprofen, a non-steroidal anti-inflammatory drug (13).

Low-dose radiation therapy has been reported to reduce the extent, density and adhesiveness of post-operative scar tissue (3).

Temozolomide was synthesized within a series of modified imidazotetrazines by Stevens et al. in 1987 (7). It establishes its cytotoxic effect especially by the transformation of guanine at the 06 position by methylation to 06-methylguanine. The cell stops at the G2/M phase transition and undergoes apoptosis as a result $(7,14)$. Inflammation and regeneration are interconnected and we therefore investigated the effectiveness of temozolomide, postulating that connective tissue formation can be limited by blocking cell proliferation.

Histological criteria including epidural fibrosis, fibroblast and inflammatory cell densities, arachnoidal adhesion, bone regeneration and cartilage regeneration as proposed by $\mathrm{He}$ et al. were used in our study to objectively evaluate epidural fibrosis in accordance with the literature (13). A statistically significant difference was found between the two groups when the extent of fibrosis in the dura mater was assessed $(p=0.0302)$. The formation of epidural fibrosis was significantly less in the Temozolomide group and no grade III fibrosis was found as shown in Table 2 . No statistically significant difference was detected with the control group for arachnoidal fibrosis, inflammatory cell density and fibroblast density. We believe that it is not possible to completely neutralize regeneration as it is the most important defense mechanism of all organisms against internal and external factors. However, it is possible to reduce dysfunctional scar formation. Similar results were obtained in the literature with a study using mitomycin- $C$ which is an anti-chemotherapeutic similar to temozolomide in terms of the mechanism of action (8).

Bone regeneration has been shown in the laminectomy defect, just like peridural fibrosis, in the majority of experimental studies. He and al. have reported that formation of new bone starts from the laminectomy site and osteoblasts are activated (13). Cook et al. have reported that bone regeneration takes place at a rate of $50 \%$ in 8 weeks and $75 \%$ in 12 weeks (6). Einhaus et al. have found a 5-10\% reduction in the laminectomy defect at the end of 4 weeks in their study (9). No significant differences were found with the control group when examining bone and cartilage regeneration in our study. Another important point is that dura mater and intradural tissues were not damaged as a side effect of temozolomide.

The effectiveness of temozolomide, which has recently become popular in the treatment of high-grade glial tumors, has been shown in experimental epidural fibrosis with the data we obtained. The safe and effective dose range of temozolomide that we administered orally to our subjects who had undergone laminectomy in our study should be determined. This agent has superior properties in the fight against fibrosis but it can block mitosis in surrounding normal tissue cells. It may also lead to necrosis and endothelial injury. In light of these factors, more common use in experimental applications and an increase in the number of test subjects are inevitable. Another negative factor is the high cost of the material at the moment.

Completely preventing fibrosis carries a risk in terms of the problems it may cause as it is necessary for tissue repair and does not seem possible. However, microsurgical intervention to reduce excessive scar formation, good hemostasis and early mobilization are considered the most effective methods in preventing epidural fibrosis. Microsurgical intervention limits the inflammatory response by causing minimum damage in the paravertebral muscles, ligamentum flavum and epidural fat tissue. Furthermore, microsurgical intervention should also be preferred as it causes less tissue loss, considering that the more the tissue loss the more the fibrosis that develops. The surgical site must be closed after good hemostasis as the inflammatory response of blood products increases fibrosis. Mobilizing patients in the early period may also be effective in reducing the severity of fibrosis due to its positive impact in terms of the quantitative and qualitative properties of wound healing.

\section{CONCLUSION}

We believe that temozolomide, an antiproliferative and antineoplastic agent used in the chemotherapeutic treatment of high-grade glial tumors, will be effective in the treatment of epidural fibrosis. The safe and effective dose range of temozolomide that we administered orally to our subjects for patients who had underwent laminectomy should be determined. This agent has superior properties in the fight against fibrosis but it can block mitosis in surrounding normal tissue cells. It is therefore necessary to conduct more experimental studies and determine its effective dose, the best administration route and clinical significance, if any.

\section{REFERENCES}

1. Abramowitz JN, Neff SR: Lumbar disc surgery: Results of the prospective lumbar discectomy. Study of the joint section and disorders of the spine and peripheral nerves of the American Association of Neurological Surgeons and Congress of Neurological Surgeons. Neurosurgery 29:301-308, 1991

2. Akın ON: Failed back surgery syndrome, in Aksoy $K$ (ed), Fundamental Neurosurgery. Vol 2. Ankara: Turkish Neurosurgical Society, 2005:1081-1089 
3. Bora H, Aykol S, Akyurek N, Akmansu M, Ataoglu O: Inhibition of epidural scar tissue formation after spinal surgery: External irradiation vs spinal membrane application. Internal Journal of Radiation Oncology Biology Physics 51 (2):507-513, 2001

4. Braverman DL, Slipman CW, Lenrow DA: Using gabapentin to treat failed back surgery syndrome caused by epidural fibrosis: A report of two cases. Arch Phys Med Rehabil 82: 691-693, 2001

5. Caner H, Altinors N, Albayrak A, Calisaneller T: Use of gore-tex in neurosurgical practice. Turkish Neurosurgery 6:108-110, 1996

6. Cook SD, Prewett AB, Dalton JE, Whitecloud TS: Reduction in perineural scar formation after laminectomy with polyactive membrane sheets. Spine 19: 1815-1825, 1994

7. D'Atri S, Tentori L, Lacal PM, Graziani G, Pagani E, Benincasa E, Zambruno G, Bonmassar E, Jiricny J: Involvement of the mismatch repair system in temozolomide-induced apoptosis. Mol Pharmacol 54: 334-341, 1998

8. Dogulu F, Kurt G, Emmez H, Erdem O, Memis L, Baykaner $\mathrm{K}$, Ceviker N: Topical mitomycin C-induced inhibition of postlaminectomy peridural fibrosis in rabbits. J Neurosurg Spine 99:76-79, 2003

9. Einhaus SL, Robertson JT, Dohan FCJ, Wujek JR, Ahmad S: Reduction of peridural fibrosis after lumbar laminotomy and discectomy in dogs by a resorbable gel Adcon-L. Spine 22:1440-1447, 1997

10. Enlace WA, Ramage EA, Lamp D, Howie SE: A type 2 (Th2 like) pattern of immune response predominates in the pulmonary interstisium of patients with cryptogenic fibrosing alveolitis (CFA). Clin Exp Immunol 101:436-441, 1995

11. Fager CA: Identification and management of radiculopathy. Neurosurgery Clinics of North America 4:1-12, 1993

12. Gill GG, Sakorvich L, Thompson E: Pedicle fat grafts for the prevention of scar formation after laminectomy. An experimental study dogs. Spine 4:176-186, 1979

13. He $Y$, Revel M, Loty B: A quantitative model of postlaminectomy scar formation. Effects of a nonsteroidal antiinflammatory drug. Spine 20: 557-563, 1995

14. Hirose Y, Berger MS, Pieper RO: Abrogation of the Chk1-mediated G2 checkpoint pathway potentiates temozolomideinduced toxicity in a p53-independent manner in human glioblastoma cells. Cancer Res 61:5843-5849, 2001
15. Kitano T, Zerwekh JE, Edwards ML, Usui Y, Allen MD: Viscous carboxymethylcellulose in the prevention of epidural scar formation. Spine 16: 820-823, 1991

16. Kurt G, Aytar MH, Dogulu F, Cemil B, Erdem O, Baykaner MK, Ceviker N: A comparison of the local effectiveness of mitomycin $C$, aprotinin, and Adcon- $L$ in experimental peridural fibrosis. Surg Neurol 70:608-613, 2008

17. Le Doux MS, Langford KH: Spinal cord stimulation for the failed back syndrome. Spine 18:191-194, 1993

18. Lee JY, Stenzel W, Ebel H, Wedekind C, Ernestus RI, Klug $\mathrm{N}$ : Mitomycin $\mathrm{C}$ in preventing spinal epidural fibrosis in a laminectomy model in rats. J Neurosurg 100:52-55, 2004

19. Lee JY, Stenzel W, Löhr M, Stützer H, Ernestus RI, Klug N: The role of mitomycin $C$ in reducing recurrence of epidural fibrosis after repeated operation in a laminectomy model in rats. J Neurosurg Spine 4:329-333, 2006

20. Ozgen S, Naderi S, Ozek MM, Pamir MN: Finding and outcome of revision lumbar disc surgery. J Spinal Disord 12:287-292, 1999

21. Phillips FM, Cunningham B: Managing chronic pain of spinal origin after lumbar surgery: The role of decompressive surgery. Spine 27:2547-2553, 2002

22. Samy AM, Hardy RW: Epidural fibrosis and the failed back surgery syndrome: History and physical findings. Neurol Res 21:S5-8, 1999

23. Shiraishi T, Crock HV: Re-exploration of the lumbar spine following simple discectomy: A review of 23 cases. Eur Spine J 4:84-87, 1995

24. Sun Y, Wang LX, Wang L, Sun SX, Cao XJ, Wang P, Feng L: A comparison of the effectiveness of mitomycin $C$ and 5-fluorouracil in the prevention of peridural adhesion after laminectomy. J Neurosurg Spine 7:423-428, 2007

25. Waddell G: Low back disability. A syndrome of Western civilization. Neurosurg Clin N Am 2:719-738, 1991

26. Yildiz KH, Gezen F, Is M, Cukur S, Dosoglu M: Mitomycin C, 5-fluorouracil, and cyclosporin A prevent epidural fibrosis in an experimental laminectomy model. Eur Spine J 16: 1525-1530, 2007

27. Zhou Q, Guo P, Wang X, Nuthalapati S, Gallo JM: Preclinical pharmacokinetic and pharmacodynamic evaluation of metronomic and conventional temozolomide dosing regimens. J Pharmacol Exp Ther 321: 265-275, 2007 